\title{
The Application of Story Telling in Pre - School Children Towards Language Ability
}

\author{
Mamik Ratnawati ${ }^{1 *}$, Monika Sawitri Prihatini ${ }^{1}$, Heni Maryati ${ }^{1}$, Ririn Probowati ${ }^{1}$, Fitri \\ Firanda Nurmalisyah ${ }^{\mathbf{1}}$, Edi Siswantoro ${ }^{2}$ \\ ${ }^{1, S T I K E S ~ P e m k a b}$ Jombang, East Java, Indonesia \\ ${ }^{2}$ STIKES Dian Husada Mojokerto, East Java, Indonesia \\ mamik.perawat@gmail.com
}

\begin{abstract}
The development of children under five is very important part. At this time, children also experience a critical period. Various forms of disease, malnutrition, lack of and love stimulation at this age will lead a negative impact that persists until adulthood even to old age. The purpose of this study is to determine the differences in language skills of children with the treatment of story telling methods without story telling.

The method this study used quasy experiment with pre test - post test design of treatment and control group. A sample of 50 children in the Nusantara and Kasih Bunda play ground in Sudimoro Village, Megaluh, Jombang. Data collection was taken from August 20 to September 6, 2018. Sampling was carried out using a simple ramdom sampling. The dependent variable in this study was language ability, the independent variable was story telling. Data analysis used t-test.

The results of study found that treatment group had an influence of story telling on language skills in pre-school children, whereas there were no differences in story telling of language skills in the treatment and control groups.

This study was expected that teacher could help children in developing children's language skills used story telling using other methods.
\end{abstract}

Keywords: Story Telling, Pre School, Language

Received December, 25, 2019; Revised January 24, 2020; Accepted February 15, 2020

(c) () () STRADA Jurnal Ilmiah Kesehatan, its website, and the articles published there in are licensed under a Creative Commons Attribution-ShareAlike 4.0 International License. 
STRADA Jurnal Ilmiah Kesehatan

DOI: $10.30994 /$ sjik.v9i1.241

ISSN: 2252-3847 (print); 2614-350X (online)

Vol.9 No.1. May 2020. Page.183-189

\section{INTRODUCTION}

Children under five years. Because they get the high and best improvement in daily live. They cover the physical and physics improvement, the improvement of children under five becomes the most important thing. In this age, children also get critical period. Various diseases, malnutrition, lack of love and lack of stimulation will give negative impact since they are in this age until mature (Kemenkes RI, 2013).

Recent study shows the problem of elderly people is related with their childhood In Lancet 2007, more than 200 million of children in the world are difficult to comprehend their optimal growth in the first five years (Allen \& Kelly, 2015). The countries which have development problems of children like cognitive delay, language, behavior, autism, and hyperactivity. The prevalence delay in language development in Indonesia has never been extensively studied. The Data in the RSCM Medical Rehabilitation Department in 2006, from 1125 children visit, found $10.13 \%$ of children diagnosed with speech and language delay. A study conducted in the Nusantara Play Group stated that the 25 children and $35 \%$ of them experiencing language skills in public.

Children who have difficulty speaking and language also influence to difficult in learning, reading and writing. This can continue into adulthood. Furthermore, adults with low academic achievement due to the delay of speech and language will affect behavioral problems and psychosocial adjustment.

Stimulation should be given early and appropriate to children's development 14, which included the ability of gross motion and subtle movements, speech and language skills, as well as the ability of socialization and independence. Optimization of children development could be done by stimulating children's abilities according to their age. The stimulation of children under 5 could provide in the form of game with learning method. One of them was the story telling method. By using story telling, it could train absorptive capacity, children's power of thought, children's concentration, and develop children's language in social interaction.

\section{METHODS}

The study used quasy experimental with pre test - post test in control group and intervention. In this design, it compare between treatment group and without story telling method with puppet stage. The populations were all pre - school children in KB Nusantara as many as 30 children and KB Kasih Bunda as many as 27 children. The sample of study as many as 25 children, the technique of sampling used simple random sampling. Dependent variable of this study was the language ability. The independent variable was story telling. The instrument used observation sheet contain 20 questions. It used to improve the language, interview, direct observation and asked to the instructor. This observation sheet was adopted from previous study and validity test. 
STRADA Jurnal Ilmiah Kesehatan

DOI: $10.30994 /$ sjik.v9i1.241

ISSN: 2252-3847 (print); 2614-350X (online)

Vol.9 No.1. May 2020. Page.183-189

RESULTS

Table 1. Distribution of respondent based on the gender of the treatment group

\begin{tabular}{lllll}
\hline \multicolumn{1}{c}{ Gender } & Frequency & Percentage $(\%)$ & Valid Percent & $\begin{array}{c}\text { Cumulative } \\
\text { Percent }\end{array}$ \\
\hline Male & 13 & 52.0 & 52.0 & 52.0 \\
\hline Female & 12 & 48.0 & 48.0 & 100.0 \\
\hline Total & 25 & 100.0 & 100.0 & \\
\hline
\end{tabular}

Source: Primary data, 2018

Table 2. Distribution of respondent based on the job of the treatment group

\begin{tabular}{lcccc} 
Job & Frequency & Percentage $(\%)$ & Valid Percent & Cumulative Percent \\
\hline Work & 7 & 28.0 & 28.0 & 28.0 \\
\hline Workless & 18 & 72.0 & 72.0 & 100.0 \\
\hline Total & 25 & 100.0 & 100.0 & \\
\hline
\end{tabular}

Source: Primary data, 2018

Table 3. Distribution of mother respondent based on the education of the treatment group

\begin{tabular}{lcccc} 
Education & Frequency & Percentage $(\%)$ & Valid Percent & Cumulative Percent \\
\hline $\begin{array}{l}\text { Middle } \\
\text { education }\end{array}$ & 23 & 92.0 & 92.0 & 92.0 \\
\hline $\begin{array}{l}\text { Higher } \\
\begin{array}{l}\text { education } \\
\text { Total }\end{array}\end{array}$ & 2 & 8.0 & 8.0 & 100.0 \\
\hline
\end{tabular}

Source: Primary data, 2018

Table 4. Distribution of respondent based on gender in control group

\begin{tabular}{lcccc}
\hline Gender & Frequency & Percentage $(\%)$ & Valid Percent & Cumulative Percent \\
\hline Male & 10 & 40.0 & 40.0 & 40.0 \\
\hline Female & 15 & 60.0 & 60.0 & 100.0 \\
\hline Total & 25 & 100.0 & 100.0 & \\
\hline
\end{tabular}

Table 5. Distribution of mother's respondent based on job in control group

\begin{tabular}{lcccc}
\hline \multicolumn{1}{c}{ Job } & Frequency & Percentage $(\%)$ & Valid Percent & Cumulative Percent \\
\hline Workless & 25 & 100.0 & 100.0 & 100.0 \\
\hline Total & 25 & 100.0 & 100.0 & \\
\hline
\end{tabular}

Source: Primary data, 2018 
STRADA Jurnal Ilmiah Kesehatan

DOI: $10.30994 /$ sjik.v9i1.241

ISSN: 2252-3847 (print); 2614-350X (online)

Vol.9 No.1. May 2020. Page.183-189

Table 6. Distribution of mother's respondent based on education in control group

\begin{tabular}{lcccc}
\hline \multicolumn{1}{c}{ Job } & Frequency & Percentage (\%) & Valid Percent & Cumulative Percent \\
\hline $\begin{array}{l}\text { Middle } \\
\text { Education }\end{array}$ & 25 & 100.0 & 100.0 & 100.0 \\
\hline Total & 25 & 100.0 & 100.0 & \\
\hline
\end{tabular}

Source: Primary data, 2018

Table 7. Distribution of frequency of story telling to the treatment and control group

\begin{tabular}{lccccccccc}
\hline & \multicolumn{3}{c}{ Pre } & \multicolumn{3}{c}{ Post } \\
\cline { 2 - 11 } & Story telling & \multicolumn{2}{c}{ Treatment } & \multicolumn{2}{c}{ Control } & \multicolumn{2}{c}{ Treatment } & \multicolumn{2}{c}{ Control } \\
& group & \multicolumn{2}{c}{ group } & \multicolumn{2}{c}{ group } & \multicolumn{2}{c}{ group } \\
& $\mathrm{f}$ & $\%$ & $\mathrm{f}$ & $\%$ & $\mathrm{f}$ & $\%$ & $\mathrm{f}$ & $\%$ \\
\hline Do & 0 & 0 & 0 & 0 & 25 & 100 & 25 & 100 \\
\hline Do not & 25 & 100 & 25 & 100 & 0 & 0 & 25 & 100 \\
\hline
\end{tabular}

Source: Primary data, 2018

Table 8. Frequency distribution of language ability to the treatment and control group

\begin{tabular}{lcccccccc}
\hline & \multicolumn{3}{c}{ Pre } & \multicolumn{3}{c}{ Post } \\
\cline { 2 - 10 } & \multicolumn{2}{c}{$\begin{array}{c}\text { Treatment } \\
\text { Language ability }\end{array}$} & \multicolumn{2}{c}{$\begin{array}{c}\text { Control } \\
\text { group }\end{array}$} & \multicolumn{2}{c}{$\begin{array}{c}\text { Treatment } \\
\text { Group }\end{array}$} & $\begin{array}{c}\text { Control } \\
\text { group }\end{array}$ \\
\cline { 2 - 10 } & $\mathrm{f}$ & $\%$ & $\mathrm{f}$ & $\%$ & $\mathrm{f}$ & $\%$ & $\mathrm{f}$ & $\%$ \\
\hline Less & 3 & 12 & 4 & 16 & 0 & 0 & 0 & 0 \\
\hline Enough & 16 & 64 & 13 & 52 & 14 & 56 & 15 & 60 \\
\hline Good & 6 & 24 & 8 & 32 & 11 & 44 & 10 & 40 \\
\hline
\end{tabular}

Table 9. Statistical result of pre intervention of treatment group and control group

\begin{tabular}{lr}
\hline & Result \\
\hline Mann-Whitney U & 268,000 \\
\hline Wilcoxon W & 593,000 \\
\hline Z &,- 866 \\
\hline Asymp. Sig. (2-tailed) &, 386 \\
\hline
\end{tabular}

Grouping Variable: Pre language

Based on table 9 the statistical test output in the Mann-Whitney test above showed that the value of Asymp. Sig. ( 2 -tailed) was 0.386 greater than the probability value of 0.05 . This showed no significant difference in language skills between two groups. Then it could be interpreted, that the two groups had the same language skills. 
STRADA Jurnal Ilmiah Kesehatan

DOI: $10.30994 /$ sjik.v9i1.241

ISSN: 2252-3847 (print); 2614-350X (online)

Vol.9 No.1. May 2020. Page.183-189

Table 10. Result statistic group at treatment and category post intervention

\begin{tabular}{lr}
\hline & Result \\
\hline Mann-Whitney U & 309,500 \\
\hline Wilcoxon W & 634,500 \\
\hline Z &,- 059 \\
\hline Asymp. Sig. (2-tailed) & 953 \\
\hline Grouping Variable: Post Language
\end{tabular}

Based on table 10 the statistical test output in the Mann-Whitney test above showed that the value of Asymp. Sig. (2 -tailed) was 0.953 greater than the probability value of 0.05 . This showed that no difference in language skills between the control and treatment groups. So it could be concluded, that there was no effect of giving story telling to children's language skills

Table 11. Statistical results of treatment groups and control groups pre and post intervention

\begin{tabular}{|c|c|}
\hline & Post - pre Treatment \\
\hline$-3,071^{b}$ & $-4,251^{b}$ \\
\hline $\begin{array}{l}\text { Asymp. } \\
\text { Sig. } \\
\text { tailed) }\end{array}$ & ,000 \\
\hline
\end{tabular}

Based on table 11 the statistical test output in the Wilcoxon test above showed that the value of Asymp. Sig. (2 -tailed) in the control group was 0.002 smaller than the probability value of 0.05 . This showed that there were differences in language skills in the control group. So it could be concluded that children's language skills changed even though no story telling. Based on the statistical test output in the Wilcoxon test above it was found that the value of Asymp. Sig. (2 -tailed) in the treatment group was 0,000 smaller than the probability value of 0.05 . This showed that there were differences in language skills between before and after treatment. Then it could be concluded that there was an effect of giving story telling to children's language skills.

Based on table 11 the statistical test output in the Wilcoxon test found that the value of Asymp. Sig. (2 -tailed) in the treatment group was 0,000 smaller than the probability value of 0.05 . This showed that differences in language skills before and after treatment. That there was an effect of giving story telling to the language ability of the children of the treatment group because during the intervention the respondents were listening to the story with puppet stage for 10 times treatment. Statistics showed that an effect of story telling on language skills in pre-school children. This was in accordance with several studies on story telling of language skills among 1) Elisa Dinasari in 2016 with the title Increased Ability to Speak through Story Telling with Puppet Media. The results showed that there was an increase in speaking skills through puppets (S. Elysa Dinasari, 2017), 2) Tri Wahyuni Tevi in 2012 with the title of Development of Oral Language Ability Through Story Telling in Group A Students at the Perwanida Duchy of Andong Boyolali RA results of study showed that the development of children's oral language skills through story telling activities (Wahyuni, 2013), 3) Yulia Indah Firyati entitled Story Telling Improved Early Childhood Language Development 


\section{STRADA Jurnal Ilmiah Kesehatan}

DOI: $10.30994 /$ sjik.v9i1.241

ISSN: 2252-3847 (print); 2614-350X (online)

Vol.9 No.1. May 2020. Page.183-189

Resulted The study showed that there was an effect of using the story telling method on the language skills of children aged 4 - 5 years in kindergarten of Nurul Amal Bandar Lampung (Yulia Indah Firyati, n.d.), and 4) Ayi Sobarna with the title Effectiveness of the Story Telling Method Media Dolls for the Development of Communicative Ability there is a correlation between story telling and communication skills (Sobarna, 2010).

Based on table 11 the statistical test output in the Wilcoxon test above showed that the value of Asymp. Sig. (2 -tailed) in the control group was 0.002 smaller than the probability value of 0.05 . This showed that a difference of the ability of the language of control group. So it could be concluded that children's language skills experience changed even though they were not given a story telling. This was because learning everyday had applied many methods of story telling even though it did not use hand puppets. Strory telling is a method that can be used to improve children's language skills, because there will be a process of getting new vocabulary (Azkiya, Psikologi, Malang, Bahasa, \& Storytelling, 2016).

Based on table 9 the statistical test output in the Mann-Whitney test found that the value of Asymp. Sig. ( 2 -tailed) was 0.386 greater than the probability value of 0.05 . This showed no significant difference in language skills between the two pre-intervention groups. Then it could be interpreted, that the two groups had same language skills. This was because maternal education in the two groups was almost the same, in the treatment group was found that most most mothers did not work the characteristics of the respondent's mother in terms of employment were no different. Another one that affect the education of mothers in the two groups was also almost the same. It was there are the point is all mother are graduated from high school. So that in two groups each has the same characteristics in terms of work. Soleymani's research also shows that there is no significant difference between strory telling and creative drama group (Soleymani, Hemmati, Rizi, \& Shahrzadi, 2017).

The statistical result showed that there was no significant difference between the treatment and control group on language skills in pre-school children as in table 5.10 the statistical test output in the Mann-Whitney test above showed that the value of Asymp. Sig. (2 -tailed) was 0.953 greater than the probability value of 0.05 . So it could be concluded that no effect of giving story telling to children's language skills. This was influenced by learning factors in the classroom where in the control group. The teacher was accustomed to giving children the opportunity to share experiences.

\section{CONCLUSION}

Based on the results of the study it could be concluded there was no significant difference between the treatment group the with control group on language skills in pre-school children because there were similarities in the characteristics of education and the work of mothers which were supporting factors in children's language stimulation. To get the difference in results, can be given to children by retelling, personal stories, and understanding stories (Storytelling, Spencer, \& Petersen, 2014).

The limitation of this study was the implementation of the method that used puppet stage for 10 times, so it was possible to bring boredom of children and lack of sample. 
STRADA Jurnal Ilmiah Kesehatan

DOI: $10.30994 /$ sjik.v9i1.241

ISSN: 2252-3847 (print); 2614-350X (online)

Vol.9 No.1. May 2020. Page.183-189

\section{REFERENCES}

Allen, L., \& Kelly, B. B. (2015). Transforming the Workforce for Children Birth Through Age 8: A Unifying Foundation.

Azkiya, N. R., Psikologi, F., Malang, U. M., Bahasa, K., \& Storytelling, L. (2016). Pengaruh Mendengarkan Dongeng terhadap kemampuan Bahasa pada Anak Prasekolah, 04(02), 123-139.

Kemenkes RI. (2013). Riset Kesehatan Dasar, Badan Penelitian dan Pengembangan Kesehatan Kementerian Kesehatan RI, Jakarta

S, E. D. (2017). Peningkatan Kemampuan Berbicara melalui Story Telling dengan Media Boneka (Penelitian Tindakan pada Kelompok A PAUD Sabrina 2016/2017), 102-114. https://doi.org/10.7763/IJSSH.2012.V2.145

Sobarna, A. Y. I. (2010). Efektivitas Metode " Storytelling " Bermedia Boneka untuk Pengembangan Kemampuan Berkomunikasi, XXVI(1), 71-80.

Soleymani, M. R., Hemmati, S., Rizi, H. A., \& Shahrzadi, L. (2017). storytelling and creative drama about personal hygiene. https://doi.org/10.4103/jehp.jehp

Storytelling, C., Spencer, T. D., \& Petersen, D. B. (2014). Effects of an Individualized.

Wahyuni, T. (2013). Pengembangan kemampuan Bahasa Lisan Melalui Story Telling pada Anak Didik kelompok A di RA Perwanida Kadipaten Andong Boyolali Tahun Pelajaran 2012/2013.

Yulia Indah Firyati, D. (2017). Story Telling Meningkatkan Bahasa Anak Usia Dini, (1). 